\title{
Intestinal Parasitic Infections in Foreigners Detected by Stool Examination in Taiwan
}

\author{
Meng-Hsuan Hsieh ${ }^{1}$,Ya-Yun Lin ${ }^{1}$, Yu-Kuei Hsu ${ }^{1}$, Jeng-Fu Yang ${ }^{1}$, Yu-Chun Hsu ${ }^{1}$, Wu-Cheng \\ $\mathrm{Chen}^{1}$, Chia-Yen Dai ${ }^{1,2}$, Ming-Lung $\mathrm{Yu}^{1,2,4}$ and Chi-Kung $\mathrm{Ho}^{*}, 3,5$ \\ ${ }^{I}$ Department of Preventive Medicine, Chung-Ho Memorial Hospital Kaohsiung Medical University, Kaohsiung, Taiwan \\ ${ }^{2}$ Department of Internal Medicine, Hepatobiliary Division, Chung-Ho Memorial Hospital Kaohsiung Medical \\ University, Kaohsiung, Taiwan \\ ${ }^{3}$ Graduate Institution of Occupational Safety and Health, Kaohsiung Medical University, Kaohsiung, Taiwan \\ ${ }^{4}$ Department of Internal Medicine, Kaohsiung Municipal Ta-Tung Hospital, Kaohsiung Medical University Hospital, \\ Kaohsiung Medical University, Kaohsiung, Taiwan \\ ${ }^{5}$ Department of Health, Kaohsiung City Government, Kaohsiung, Taiwan
}

\begin{abstract}
Many foreigners enter Taiwan for the purpose of marriage or study, or as dependants or relatives of Taiwanese citizens. The aim of this study was to investigate the proportions of these immigrants infected with intestinal parasites. A total of 2875 foreigners from 39 countries or regions underwent stool examination in our hospital within the study period, and the merthiolate iodine formaldehyde method was used to diagnose intestinal parasite infections. In total, 214 foreigners $(7.4 \%)$ were found to be infected, and hookworm was identified as the most prevalent intestinal parasite (2.92\%). Infection was most prevalent in the Vietnamese foreigners $(46.3 \%)$, followed by the Chinese $(38.8 \%)$, and was more prevalent in females $(92.3 \%)$ than in males. Among the intestinal parasites identified, hookworm $(2.92 \%)$, Trichuris trichiura $(1.18 \%)$, and Blastocystis hominis $(1.14 \%)$ were the three most prevalent. Infection was most prevalent in the foreign brides group (11.9\%), hookworm and Trichuris trichiura being the two most common species of intestinal parasite in the foreign brides and foreign dependants/relatives of Taiwanese citizens, while the proportion of foreign students infected was lower. Most foreigners enter Taiwan for the purpose of marriage or study, or as dependants/relatives of Taiwanese citizens, and originate from countries or regions in which public health is poorer than in Taiwan. Therefore, close monitoring and examination of these foreigners continue to be indicated.
\end{abstract}

Key words: Stool examination, intestinal parasites, foreigner, Taiwan.

\section{INTRODUCTION}

Intestinal parasites are common worldwide, with high proportions of the population infected in regions of lower socioeconomic status and areas with low standards of hygiene [1]. It has been estimated that approximately 3.5 billion people are affected worldwide, 450 million of whom are ill as a result of infection, the majority being children [2]. The endemicity of these fecal-, soil- and water-borne diseases is an indication of commonality in both urban and rural disadvantaged communities, where living conditions, environmental cleanliness, and personal and domestic hygiene are poor $[1,2]$.

More than one million foreigners enter Taiwan every year [3]. Except those who do so for sightseeing, business, or other special purposes, the large majority enter Taiwan for the purpose of work, marriage or study, or as dependants or relatives of Taiwanese citizens. These foreigners are requested to undergo examination for intestinal parasites [4],

*Address correspondence to this author at the Department of Health, Kaohsiung City Government, 132 Kaisyuan $2^{\text {nd }}$ Road, Lingya District, Kaohsiung 802, Taiwan; Tel: Tel: +886-7-3121101; Ext. 6863; Fax: +8867-3115948; E-mail: hochikung@yahoo.com which can help to prevent infections entering Taiwan from other countries or regions.

Several previous studies of intestinal parasite infections in immigrants to Taiwan have been performed [5-17]. However, the subjects of most of these studies have been foreign laborers, and very little research has focused on those entering Taiwan for the purpose of marriage or study, or as relatives or dependants of Taiwanese citizens. The aim of this study was therefore to assess the proportion of foreigners entering Taiwan for the purpose of marriage or study, or as dependants or relatives of Taiwanese citizens, who are suffering from intestinal parasitic infections.

\section{MATERIALS AND METHODOLOGY}

\section{Subjects}

Foreigners entering Taiwan for the purpose of work, marriage or study, or as dependants or relatives of Taiwanese citizens, who underwent a health examination in Kaohsiung Medical University Hospital between January 2006 and November 2008 were enrolled in this study. The inclusion criterion was that the foreigners match the regulations of the Centers for Disease Control (CDC); those who did not were excluded. In total, 2875 foreigners from 39 countries or 
regions were enrolled. This research was approved by the Institutional Review Board (IRB) of Kaohsiung Municipal Hsiaokang Hospital.

\section{Regulations of the Centers for Disease Control (CDC)}

According to the regulations of the Centers for Disease Control (CDC) 2008, Blastocystis hominis (Bh), Entamoeba hartmanni (Eha), Entamoeba coli (Ec), Endolimax nana (En), Iodamoeba butschlii (Ib) and Dientamoeba fragilis (Df) need no treatment. Other parasitic infections, with the exception of Entamoeba histolytica/dispar, for which stools must be reexamined in 7 days so as to distinguish E. histolytica from E. dispar by polymerase chain reaction (PCR) gene detection, require treatment, and stools should be re-examined in 45 days (2008)[18].

\section{Stool Examination}

Stool samples were transferred for examination within 30 minutes of passage and the examination completed within the next 30 minutes. The merthiolate iodine formaldehyde (MIF) method, the stool examination method recommended by the CDC, according Sapero and Lawless [19], was used. A $4.7-\mathrm{ml}$ sample of merthiolate-formaldehyde solution and $0.3 \mathrm{ml}$ of iodine solution were mixed in a bottle and a stool sample of a volume similar to that of the thumb distal phalanx was added. Soon after, the MIF-stool sample was filtered through gauze, ether was added, and the filtered solution was centrifuged at $2000 \mathrm{rpm}$ for 2 minutes. The upper layer of clear fluid was then discarded and the residue examined under a microscope (Olympus BX41, Japan).

\section{Statistical Analysis}

Descriptive statistics such as frequency and percentage were used for statistical analysis in this study, which was performed using the SPSS statistical package (SPSS Inc., Chicago, IL, USA).

\section{RESULTS}

The basic demographic characteristics of the subjects enrolled in this study are listed in Table 1. The highest proportion of the subjects were Chinese $(1426 / 2875,49.6 \%)$, followed by Southeast Asian (965/2875, 33.6\%, including Vietnamese $[660 / 2875,23.0 \%]$ and Indonesian subjects [119/2875, 4.1\%], not shown in table). Chinese subjects also constituted the highest proportions of those foreigners present in Taiwan as a dependant or relative of a Taiwanese citizen $(1141 / 1845,61.8 \%)$ and those in Taiwan for the purpose of study $(168 / 326,51.5 \%)$, while foreigners from Southeast Asia constituted the greatest proportion of immigrants to Taiwan for the purpose of marriage, i.e., foreign brides $(580 / 70482.4 \%$, including Vietnamese $443 / 704,62.9 \%$, not shown in table). The proportion of female subjects was greater than that of males $(2426 / 2875$, $84.4 \%$ ), and more than $90 \%$ of the subjects originating from China and Southeast Asia (especially Vietnam and Indonesia, not shown in table) were female. However, of the foreign students originating from Myanmar (not shown in table), South Asia, the USA, Canada, Europe, Africa and Oceania, the majority were male. The study subjects ranged in age from 1 to 89 years; the average age of the male subjects was lower than that of the females, and the foreign students were younger on average than the other two groups (foreign brides and dependents/relatives of Taiwanese citizens; Table 1).

In our study, a total of 214 foreigners from 12 countries

Table 1. Basic Demographic Characteristics of the Subjects Enrolled in the Study (n (\%))

\begin{tabular}{|c|c|c|c|c|c|c|c|c|c|c|}
\hline \multirow{2}{*}{ Country or Region } & \multirow{2}{*}{$\begin{array}{c}\text { Foreign Brides } \\
\text { Female }\end{array}$} & \multicolumn{3}{|c|}{$\begin{array}{c}\text { Foreign Dependants or } \\
\text { Relatives of Taiwanese Citizens }\end{array}$} & \multicolumn{3}{|c|}{ Foreign Students } & \multicolumn{3}{|c|}{ All Foreigners } \\
\hline & & Male & Female & Total & Male & Female & Total & Male & Female & Total \\
\hline China, Hong and Macau & 120 & $52(4.5)$ & $1112(95.5)$ & 1164 & $114(49.6)$ & $116(50.4)$ & 230 & $166(11.0)$ & $1348(89.0)$ & 1514 \\
\hline Japan and Korea & 2 & $27(31.0)$ & $60(69.0)$ & 87 & $8(42.1)$ & $11(57.9)$ & 19 & $35(32.4)$ & $73(67.6)$ & 108 \\
\hline United States of America & - & $52(57.8)$ & $38(42.2)$ & 90 & $9(60.0)$ & $6(40.0)$ & 15 & $61(58.1)$ & $44(41.9)$ & 105 \\
\hline Canada & 2 & $43(71.7)$ & $17(28.3)$ & 60 & $8(72.7)$ & $3(27.3)$ & 11 & $51(69.9)$ & $22(30.1)$ & 73 \\
\hline Latin America* & - & $7(46.7)$ & $8(53.3)$ & 15 & $1(50.0)$ & $1(50.0)$ & 2 & $8(47.1)$ & $9(52.9)$ & 17 \\
\hline Total & 704 & $275(14.9)$ & $1570(85.1)$ & 1845 & $174(53.4)$ & $152(46.6)$ & 326 & $449(15.6)$ & $2426(84.4)$ & 2875 \\
\hline
\end{tabular}

-: Cannot be estimated.

*: Southeast Asia: Vietnam (660), Indonesia (119), the Philippines (52), Malaysia (52), Myanmar (31), Cambodia (22), Thailand (20) and Singapore (9). South Asia: India (2) and Pakistan (2). Latin America: Brazil (9), Argentina (6), Salvador (1) and Paraguay (1). Europe: the United Kingdom (23), Germany (13), France (5), Portugal (5), Holland (3),

Ukraine (2), Austria (2), Russia (2), Switzerland (1), Finland (1), Romania (1), Belgium (1) and Hungary (1). Africa: South Africa (10), Tanzania (2) and Egypt (1). Oceania: Australia (11), New Zealand (4) and Fiji (1). (Values in parentheses indicate the number of foreigners).

Average age (mean \pm standard deviation, years) of all foreigners included in this study: males: $25.86 \pm 12.95$; females: $30.40 \pm 09.64$; foreign brides: $29.16 \pm 6.30$; dependants or relatives of Taiwanese citizens: $31.48 \pm 11.39$; foreign students: $20.70 \pm 5.25$. 
Table 2. Proportions of Subjects Infected with Intestinal Parasites by Nationality and Reason for Immigrating to Taiwan (n (\%))

\begin{tabular}{|c|c|c|c|c|c|c|c|c|c|c|}
\hline \multirow{2}{*}{ Country or Region } & \multirow{2}{*}{$\begin{array}{c}\text { Foreign Brides } \\
\text { Female }\end{array}$} & \multicolumn{3}{|c|}{$\begin{array}{c}\text { Foreign Dependants or } \\
\text { Relatives of Taiwanese Citizens }\end{array}$} & \multicolumn{3}{|c|}{ Foreign Students } & \multicolumn{3}{|c|}{ Total } \\
\hline & & Male & Female & Total & Male & Female & Total & Male & Female & Total \\
\hline Vietnam & 65 & $0(0.00)$ & $34(100.0)$ & 34 & - & - & - & $0(0.0)$ & $99(100.0)$ & 99 \\
\hline China & 11 & $1(1.5)$ & $65(98.5)$ & 66 & $4(66.7)$ & $2(33.3)$ & 6 & $5(6.0)$ & $78(94.0)$ & 83 \\
\hline Indonesia & 6 & - & - & 0 & - & - & - & $0(0.0)$ & $6(100.0)$ & 6 \\
\hline Myanmar & - & $1(50.0)$ & $1(50.0)$ & 2 & $3(100.0)$ & $0(0.00)$ & 3 & $4(80.0)$ & $1(20.0)$ & 5 \\
\hline Hong and Macau & - & - & - & - & $3(75.0)$ & $1(25.0)$ & 4 & $3(75.0)$ & $1(25.0)$ & 4 \\
\hline Canada & - & $0(0.00)$ & $1(100.0)$ & 1 & $1(100.0)$ & $0(0.00)$ & 1 & $1(50.0)$ & $1(50.0)$ & 2 \\
\hline Russia & - & - & - & - & $1(100.0)$ & $0(0.00)$ & 1 & $1(0.0)$ & $\begin{array}{lll}0 & (0.0)\end{array}$ & 1 \\
\hline Korea & - & $0(0.00)$ & $1(100.0)$ & 1 & - & - & - & $0(0.0)$ & $1(100.0)$ & 1 \\
\hline Total & 84 & $3(2.6)$ & $112(97.4)$ & 115 & $12(80.0)$ & $3(20.0)$ & 15 & $15(7.0)$ & $199(92.3)$ & 214 \\
\hline
\end{tabular}

-: cannot be estimated.

Total rate of infection: $7.4 \%(214 / 2875)$.

or regions were found to be infected with intestinal parasites, with an overall infection rate of $7.4 \%$ (214/2875). Among the foreigners examined, intestinal parasite infections were most prevalent in the Vietnamese $(46.3 \%, 99 / 214)$, followed by the Chinese $(38.8 \%, 83 / 214)$, and fewer than 7 foreigners from other countries or regions were found to be infected with intestinal parasites. A greater proportion of the female subjects suffered from infection than of the males $(92.3 \%$, 199/214). The proportion of infected subjects was highest in the group of foreign dependants or relatives of Taiwanese citizens. Of the Vietnamese subjects, infection was most common in the foreign brides, while of the Chinese subjects, infection was most prevalent in the group of dependants or relatives Taiwanese citizens (Table 2).

In this study, the female foreigners infected by intestinal parasites were generally older than the infected males, and the dependants/relatives of Taiwanese citizens infected by intestinal parasites were older than the infected foreign

Table 3. Proportions of Subjects Infected with Intestinal Parasites by Reason for Immigrating to Taiwan, Gender, and Age (n (\%))

\begin{tabular}{|c|c|c|c|c|c|c|c|c|c|c|c|c|c|}
\hline \multirow[b]{3}{*}{$\begin{array}{c}\text { Age Range } \\
\text { (Yrs) }\end{array}$} & \multicolumn{4}{|c|}{ Gender } & \multicolumn{6}{|c|}{ Reason for Immigrating to Taiwan } & \multirow{2}{*}{\multicolumn{3}{|c|}{ Total }} \\
\hline & \multicolumn{2}{|c|}{$\begin{array}{c}\text { Total } \\
(p<0.001)\end{array}$} & \multicolumn{2}{|c|}{$\begin{array}{c}\text { Infected } \\
(p<0.001)\end{array}$} & \multicolumn{3}{|c|}{$\begin{array}{c}\text { Total } \\
(p<0.001)\end{array}$} & \multicolumn{3}{|c|}{$\begin{array}{c}\text { Infected } \\
(p<0.001)\end{array}$} & & & \\
\hline & Male & Female & Male & Female & $\begin{array}{c}\text { Foreign } \\
\text { brides }\end{array}$ & $\begin{array}{c}\text { Foreign } \\
\text { Dependants } \\
\text { or } \\
\text { Relatives } \\
\text { of } \\
\text { Taiwanese } \\
\text { Citizens }\end{array}$ & $\begin{array}{l}\text { Foreign } \\
\text { Students }\end{array}$ & $\begin{array}{c}\text { Foreign } \\
\text { Brides }\end{array}$ & $\begin{array}{c}\text { Foreign } \\
\text { Dependants or } \\
\text { Relatives } \\
\text { of Taiwanese } \\
\text { Citizens }\end{array}$ & $\begin{array}{c}\text { Foreign } \\
\text { Students }\end{array}$ & Normal & Infected & Total \\
\hline $0-20$ & $\begin{array}{r}202 \\
(45.0)\end{array}$ & $\begin{array}{r}212 \\
(8.7)\end{array}$ & $\begin{array}{r}7 \\
(46.7)\end{array}$ & $\begin{array}{r}7 \\
(3.5)\end{array}$ & $\begin{array}{r}7 \\
(1.0)\end{array}$ & $\begin{array}{r}172 \\
(9.3)\end{array}$ & $\begin{array}{r}235 \\
(72.1)\end{array}$ & $\begin{array}{r}0 \\
(0.0)\end{array}$ & $\begin{array}{r}6 \\
(5.2)\end{array}$ & $\begin{array}{r}8 \\
(53.3)\end{array}$ & $\begin{array}{r}400 \\
(96.6)\end{array}$ & $\begin{array}{r}14 \\
(3.4)\end{array}$ & 414 \\
\hline $21-35$ & $\begin{array}{r}153 \\
(34.1)\end{array}$ & $\begin{array}{r}1604 \\
(66.1)\end{array}$ & $\begin{array}{r}7 \\
(46.7)\end{array}$ & $\begin{array}{r}155 \\
(77.9)\end{array}$ & $\begin{array}{r}592 \\
(84.1)\end{array}$ & $\begin{array}{r}1083 \\
(58.7)\end{array}$ & $\begin{array}{r}82 \\
(25.2)\end{array}$ & $\begin{array}{r}74 \\
(88.1)\end{array}$ & $\begin{array}{r}81 \\
(70.4)\end{array}$ & $\begin{array}{r}7 \\
(46.7)\end{array}$ & $\begin{array}{r}1595 \\
(90.8)\end{array}$ & $\begin{array}{r}162 \\
(9.2)\end{array}$ & 1757 \\
\hline$>35$ & $\begin{array}{r}94 \\
(20.0)\end{array}$ & $610(25.2)$ & $\begin{array}{r}1 \\
(6.6)\end{array}$ & $\begin{array}{r}37 \\
(18.6)\end{array}$ & $\begin{array}{r}105 \\
(14.9)\end{array}$ & $\begin{array}{r}590 \\
(32.0)\end{array}$ & $\begin{array}{r}9 \\
(2.7)\end{array}$ & $\begin{array}{r}10 \\
(11.9)\end{array}$ & $\begin{array}{r}28 \\
(24.3)\end{array}$ & $\begin{array}{r}0 \\
(0.0)\end{array}$ & $\begin{array}{r}666 \\
(94.6)\end{array}$ & $\begin{array}{r}38 \\
(5.40)\end{array}$ & 704 \\
\hline total & $\begin{array}{r}449 \\
(100.0)\end{array}$ & $\begin{array}{r}2426 \\
(100.0)\end{array}$ & $\begin{array}{r}15 \\
(100.0)\end{array}$ & $\begin{array}{r}199 \\
(100.0)\end{array}$ & $\begin{array}{r}704 \\
(100.0)\end{array}$ & $\begin{array}{r}1845 \\
(100.0)\end{array}$ & 326 & $\begin{array}{r}84 \\
(100.0)\end{array}$ & $\begin{array}{r}115 \\
(100.0)\end{array}$ & $\begin{array}{r}15 \\
(100.0)\end{array}$ & $\begin{array}{r}2661 \\
(92.6)\end{array}$ & $\begin{array}{r}214 \\
(7.4)\end{array}$ & 2875 \\
\hline
\end{tabular}

Average age (mean \pm standard deviation) of infected foreigners in this study: males: $23.20 \pm 5.43$; females: $28.81 \pm 8.04$ (gender comparison, $p=0.009$ ); foreign brides: $27.44 \pm 5.29$; dependants or relatives of Taiwanese citizens: $29.97 \pm 9.42$; foreign students: $22.00 \pm 4.07$ (reason for immigrating to Taiwan comparison, $p<0.001$ ). 
Table 4. Proportions of Subjects Infected with Intestinal Parasites by Nationality

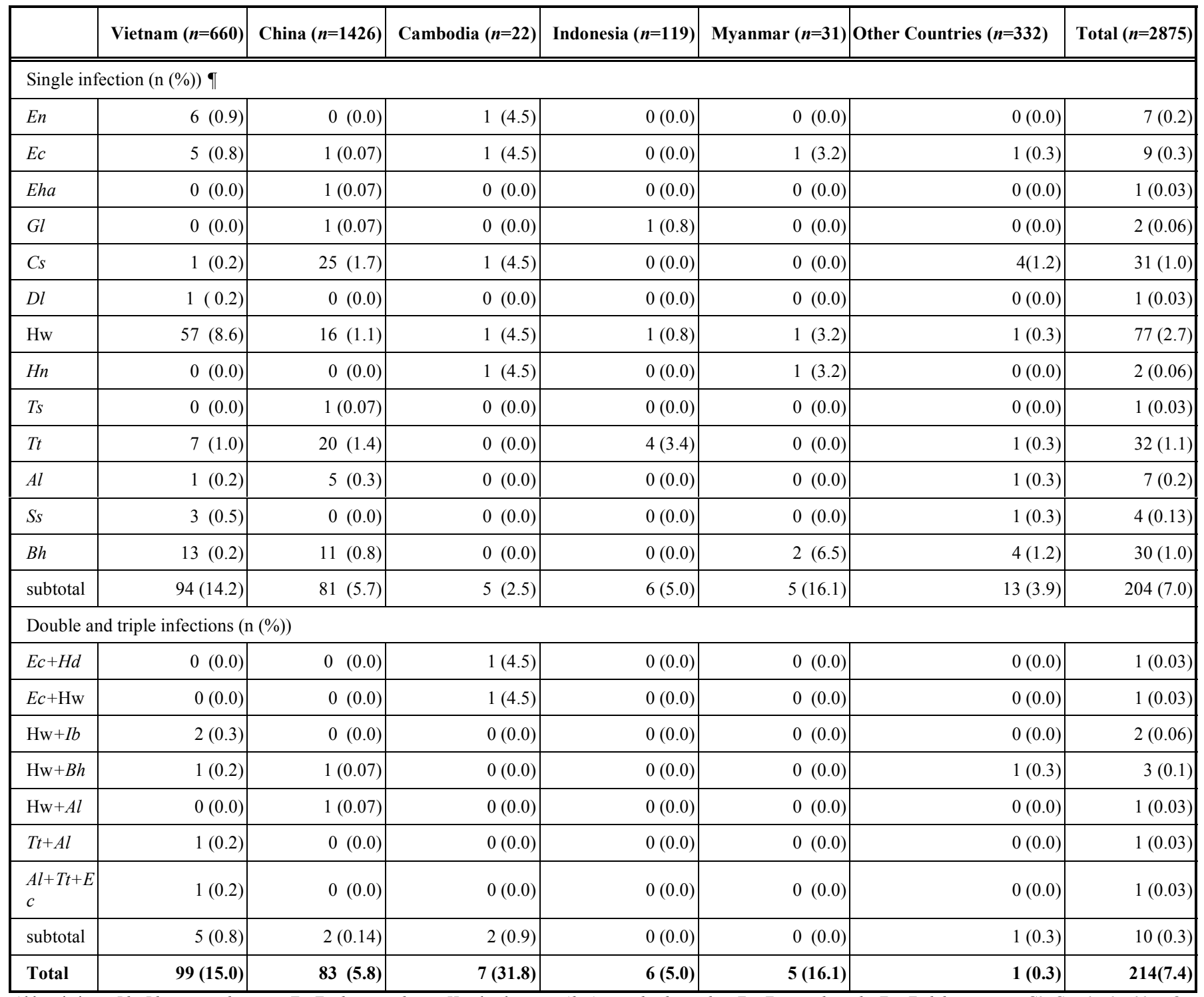

Abbreviations: Bh: Blastocystis hominis; Tt: Trichuris trichiura; Hw: hookworm; Al: Ascaris lumbricoides; Ec: Entamoeba coli; En: Endolimax nana; Gl: Giardia lamblia; Ov: Opisthorchis viverrini; Ehi: Entamoeba histolytica; Ed: Entamoeba dispar; Ss: Strongyloides stercoralis; To: Trichostrongylus orientalis; Eha: Entamoeba hartmanni; Ib. Iodamoeba butschlii; Cs: Clonorchis sinensis; Dl: Diphyllobothrium latum; Hn: Hymenolepis nana; Ts: Trichostrongyms spp; Hd: Hymenolepis diminuta; Ib: Iodamoeba butochilii. *: Other countries: Hong Kong and Macau: $C s(3), B h(1)$. Canada: Hw (1), Bh(1). Japan: Bh(2). The Philippines: $T t(1), A l(1)$. Brazil: $S s(1)$, Hw+Bh (1). Russia: Ec(1). Korea Cs(1).

**: including other countries

T: percentage $=$ infected foreigners of one country or region/total foreigners of one country or region.

brides or students (Table 3). In addition, there were significant differences in terms of age and gender/age and reason for immigrating to Taiwan in the infected foreigners (Table 3), and the average age between genders and the reason for immigrating to Taiwan also differed significantly (Table 3).

Stool samples were analyzed for a total of 15 species of intestinal parasite in this study: 204 foreigners were found to be infected by one kind of intestinal parasite, and 10 were infected with two or more kinds of intestinal parasites (Table 4). Infection was most prevalent in the Vietnamese foreigners, followed by the Chinese, and hookworm $(84 / 2875,2.92 \%)$, Trichuris trichiura $(34 / 2875,1.18 \%)$, and Blastocystis hominis $(33 / 2875,1.14 \%)$ were the three most common intestinal parasites. In addition, in the Vietnamese subjects, hookworm was the most prevalent intestinal parasite, while Clonorchis sinensis and Trichuris trichiura were the most two prevalent intestinal parasites in the Chinese. Two Japanese subjects (infected by Blastocystis hominis) and 1 Russian subject (infected by Entamoeba coli) were infected by intestinal parasites that required no treatment, but one Korean was infected with intestinal parasites that required treatment (Table 4). In terms of the foreigners' reasons for immigrating to Taiwan, infections were most prevalent in the foreign brides $(11.9 \%)$, followed by the dependants or relatives of Taiwanese citizens $(6.2 \%)$. Hookworm and Trichuris trichiura were the two most prevalent species of intestinal parasites in the foreign brides, and hookworm, Trichuris trichiura, and Clonorchis sinensis were the most prevalent three kinds of intestinal parasites in the foreign dependants or relatives of Taiwanese citizens. The infection rate in foreign students was low, Clonorchis 
Table 5. Proportions of Subjects Infected with Intestinal Parasites by Reason for Immigrating to Taiwan

\begin{tabular}{|c|c|c|c|c|}
\hline & $\begin{array}{r}\text { Foreign Brides } \\
(n=704)\end{array}$ & $\begin{array}{r}\text { Foreign Dependants or Relatives of Taiwanese Citizens } \\
(n=1845)\end{array}$ & $\begin{array}{r}\text { Foreign Students } \\
(n=326)\end{array}$ & $\begin{array}{r}\text { Total } \\
(n=2875)\end{array}$ \\
\hline En & $5(0.7)$ & $2(0.1)$ & $0(0.0)$ & $7(0.2)$ \\
\hline$E c$ & $3(0.4)$ & $5(0.2)$ & $1(0.3)$ & $9(0.3)$ \\
\hline$G l$ & $2(0.2)$ & $0(0.0)$ & $0(0.0)$ & $2(0.06)$ \\
\hline Cs & $1(0.1)$ & $21(1.1)$ & $9(2.7)$ & $31(1.0)$ \\
\hline$D l$ & $1(0.1)$ & $0(0.0)$ & $0(0.0)$ & $1(0.03)$ \\
\hline $\mathrm{Hw}$ & $47(6.7)$ & $28(1.5)$ & $2(2.6)$ & $77(2.7)$ \\
\hline$A l$ & $0(0.0)$ & $7(0.3)$ & $0(0.0)$ & $7(0.2)$ \\
\hline Ss & $3(0.4)$ & $1(0.05)$ & $0(0.0)$ & $4(0.13)$ \\
\hline$B h$ & $8(1.1)$ & $19(1.0)$ & $3(0.9)$ & $30(1.0)$ \\
\hline total & $81(11.5)$ & $108(5.9)$ & $15(4.6)$ & $204(7.0)$ \\
\hline \multicolumn{5}{|c|}{ Double and triple infections (n (\%)) } \\
\hline$E c+H d$ & $0(0.0)$ & $1(0.05)$ & $0(0.0)$ & $1(0.03)$ \\
\hline$E c+\mathrm{Hw}$ & $0(0.0)$ & $1(0.05)$ & $0(0.0)$ & $1(0.03)$ \\
\hline $\mathrm{Hw}+I b$ & $1(0.1)$ & $1(0.05)$ & $0(0.0)$ & $2(0.06)$ \\
\hline Total & 84 (11.9) & $115(6.2)$ & 15 (4.6) & $214(7.4)$ \\
\hline
\end{tabular}

Abbreviations: Bh: Blastocystis hominis; Tt: Trichuris trichiura; Hw: Hookworm; Al: Ascaris lumbricoides; Ec: Entamoeba coli; En: Endolimax nana; Gl: Giardia lamblia; Ov: Opisthorchis viverrini; Ehi: Entamoeba histolytica; Ed: Entamoeba dispar; Ss:Strongyloides stercoralis; To: Trichostrongylus orientalis; Eha: Entamoeba hartmanni; Ib: Iodamoeba butschlii; Cs: Clonorchis sinensis; Dl: Diphyllobothrium latum; Hn: Hymenolepis nana; Ts: Trichostrongyms spp; Hd: Hymenolepis diminuta; Ib: Iodamoeba butochilii. T: percentage $=$ infected foreigners of one country or region/total foreigners of one country or region.

sinensis being the most common intestinal parasite in that group (Table 5).

\section{DISCUSSION}

From our data, the majority of foreigners entering Taiwan for the purpose of marriage or study, or as dependants or relatives of Taiwanese citizens were found to originate from Asia, in particular China, Vietnam, and Indonesia, and, with the exception of Asians, the next greatest proportion of foreigners entering Taiwan originated from North America (the USA and Canada). The foreign brides and foreign dependants or relatives of Taiwanese citizens came from Asia in most cases, most commonly China and Vietnam, and the foreign students originated mainly from China. In addition, whatever their country of origin, the foreign students numbered fewer than the foreign brides and foreign dependants or relatives of Taiwanese citizens, and the proportion of female immigrants was greater than that of the males. These results might reflect the current migration status between Taiwan and other countries, especially China.

In our study, almost all of the infected foreigners originated from Asia, in particular Vietnam and China, and no foreigners from Africa, South Asia, or Oceania were found to be infected with intestinal parasites. This may be due to the fact that fewer foreigners originating from these areas were included in the study. Moreover, the results probably do not reflect the actual proportions of the populations of these areas who are infected with parasites. With the exception of foreign students, the proportion of infected female foreigners was greater than that of males. Furthermore, significant differences in the proportions of subjects infected between genders and between the groups with different reasons for immigrating to Taiwan were observed. This is likely due to the greater proportion of 
females coming to Taiwan for the purpose of marriage and as foreign dependants or relatives of Taiwanese citizens. In addition, significant differences in the proportions of infected subjects were observed between the genders and the different age ranges, and there were significant differences in age between the groups with different reasons for immigrating to Taiwan. This might be related to the fact that, foreign students accepted, most of the infected subjects were aged between 21 and 35 .

In our study, foreigners from 12 countries or regions were found to be infected with intestinal parasites. Hookworm was the most prevalent intestinal parasite, and most of the subjects infected with this parasite were from Vietnam; most of those infected with Trichuris trichiura and Clonorchis sinensis were Chinese, and Blastocystis hominis was also dominant in the Vietnamese and Chinese subjects. The proportions of Cambodian, Indonesian and Myanmarian subjects infected with parasites were all greater than $5 \%$, but the numbers of subjects examined were low: there were 119 Indonesian subjects, and only 22 and 31 subjects from Cambodia and Myanmar, respectively. However, even though the numbers of subjects originating from these countries were low, public health is likely to be quite poor in those areas, and we therefore consider the results to be reliable. Infections were rare in the foreigners originating from countries other than those mentioned above, probably as a result of a better public health environment. Previous studies have shown that Angiostrongylus cantonensis, Clonorchis sinensis and Taenia saginata are the most common food-borne parasites in Taiwan [20,21], and we found that the prevalence of food-borne parasites in the Taiwanese differs from that in foreigners originating from southeast Asia, especially the Vietnamese. However, the results are similar to that of China, and Clonorchis sinensis was most common in the Chinese immigrants in our study. This could be due to the similar dietary habits and geographic environments in Taiwan and China, especially in Chinese originating from southern China.

Our study also showed that, among the groups of subjects immigrating to Taiwan for different reasons, the proportion of infected subjects was highest in the foreign brides, followed by dependants/relatives of Taiwanese citizens, and finally foreign students, in whom the infected proportion was the smallest. Hookworm and Trichuris trichiura were the two most prevalent parasitic infections in the foreign brides and dependants or relatives of Taiwanese citizens, and Clonorchis sinensis was also prevalent in the latter group. The distributions of parasitic infection in the Vietnamese and Chinese subjects were similar, which is reasonable for these two groups of foreigners. In studies of foreign laborers conducted prior to 2002 in Taiwan, O. viverrinii was identified as the most prevalent parasitic infection in foreign laborers [10, 22, 23]; however, Blastocystis hominis became the most common intestinal parasite identified in foreigners by health examination in Taiwan after identification of this parasite by stool examination was added to the CDC list of infections to be screened for in foreign laborers in 2002 [5, $9,11,13]$. In our previous study, $4.5 \%$ of foreign laborers were found to be infected with intestinal parasites, and Blastocystis hominis was identified as the most prevalent, followed by Trichuris trichiura and hookworm [6]. In this study, hookworm, Trichuris trichiura and Blastocystis hominis were again identified as the dominant parasites. It was reported in another study that, of the Vietnamese female subjects who immigrated to Taiwan for marriage, $37.7 \%$ were infected with intestinal parasites, the greatest proportion of whom were infected with Blastocystis or hookworm [13]. The infection rate of Vietnamese brides was found in our study to be $9.2 \%(65 / 704)$, and for all foreign brides was $11.9 \%$, with Blastocystis and hookworm being most dominant in the Vietnamese subjects. The reasons for which the foreigners included in our study remained in Taiwan differed from those of the subjects enrolled in previous studies, but the dominant intestinal parasites were similar. As most of the foreigners in this study originated from China and Vietnam, this finding reflects the similarities in the parasitic infection distributions of these areas.

A previous study of the proportions of foreign laborers from Thailand, The Philippines, and Indonesia with parasitic infections between 1992 and 1995 reported figures of $60 \%$, $20 \%$ and $4 \%$, respectively [22]. In our previous study, the infection rates of Indonesian, Thai, Filipino, and Vietnamese laborers were found to be $5.9 \%, 2.0 \%, 3.5 \%$, and $6.6 \%$, respectively [6]. However, in this study, the proportions of Indonesian, Thai, Filipino, and Vietnamese foreigners infected were found to be much lower than those previously reported, at $0.2 \%(6 / 2875), 0 \%, 0.07 \%(2 / 2875)$, and $3.4 \%$ (99/2875). In addition, the infection rate was lowest in foreign students among the groups with different reasons for immigrating to Taiwan, perhaps because these foreigners were of higher economic and social status. The present findings may be due to the fact that the foreigners examined were not laborers, and therefore of higher economic and social status than others in their country or region. Alternatively, public health might have become of higher standards in their countries of origin.

Because this was a hospital-based study, there were several limitations. First, we were not able to follow-up infected subjects, because most did not visit our hospital for treatment. Moreover, some of the findings were positive, but the infections (e.g., $B h, I b$ and $D f$ ) did not require treatment. Second, the results may not reflect the prevalence of infection in the countries or regions from which the subjects examined originated - rather, we were only able to indicate the proportion of immigrants to Taiwan in whom stool examination for parasites was positive. Third, we were unable to explain some of the findings of this study, because we were not able to acquire some of the information necessary for further analysis and interpretation of the results, such as public health data, local stool parasite examination data, etc. Finally, the number of subjects originating from some countries was low in this study, and therefore comparison of the proportions of infected subjects from these countries could not be reliably performed. A further study is warranted in order to conduct a more detailed survey.

\section{CONCLUSIONS}

Foreigners originating from the same areas might be infected with similar intestinal parasites, but the infection rates are generally lower in foreigners of higher economic and social status as compared to others in their countries or regions. Because most foreigners who enter Taiwan for the 
purpose of marriage or study, or as dependants or relatives of Taiwanese citizens, come from countries or regions in which public health is poorer than in Taiwan, close monitoring and examination of these foreigners continue to be required.

\section{CONFLICT OF INTEREST}

There are no conflicts of interest for any of the authors of this study.

\section{ACKNOWLEDGEMENT}

This study was conducted with assistance from the Department of Occupational Medicine, Kaohsiung Municipal Hsiao Kang Hospital, Kaohsiung, Taiwan.

\section{REFERENCES}

[1] Bunnag D, Cabrera BD, Crompton DWT, et al. Prevention and control intestinal parasitic infections. In., vol. World Health Organization Technical Report Series 749. Geneva: World Health Organization 1987.

[2] Okyay P, Ertug S, Gultekin B, Onen O, Beser E. Intestinal parasites prevalence and related factors in school children, a western city sample--Turkey. BMC Public Health 2004; 4: 64.

[3] Statistics of Various Type, National Immigration Agency [http://www.immigration.gov.tw//immig_eng/aspcode/main11.asp]

[4] Items Required for Health Certificate (Type B) [http://mail.tit.edu.tw/ cia/file/download/application/health.pdf]

[5] Cheng HS, Guo YL, Shin JW. Hematological effects of Blastocystis hominis infection in male foreign workers in Taiwan. Parasitol Res 2003; 90: 48-51.

[6] Hsieh MH, Lin WY, Dai CY, et al. Intestinal parasitic infection detected by stool examination in foreign laborers in Kaohsiung. Kaohsiung J Med Sci 2010; 26: 136-43.

[7] Fan P, Peng H. Parasite infections among foreign laborers in Taiwan with special emphasis on Opisthorchis viverrini. Chinese journal of parasitology 1993; 6: 21-7.

[8] Lo CT, Lee KM, Kee KF. Intestinal parasites among the Southern Asian laborers in Taiwan during 1993-1994. Chinese Med J 1996; 57: 401-4
[9] Jang M-H, Lin L-Y, Hsu SH-J. Survey of Parasites Infection among Foreign Laborers. Taipei City Med J 2007; 4: 808-13.

[10] Yen C, Tsen L, Leu S, Chung L, Hsieh H, Chen E. Investigation on the parasites of alien laborers in Kaohsiung. Kaohsiung J Med Sci 1995; 11: 390-7.

[11] Wang LC. Changing patterns in intestinal parasitic infections among Southeast Asian laborers in Taiwan. Parasitol Res 2004; 92 : $18-21$.

[12] Peng HW, Chao HL, Fan PC. Imported Opisthorchis viverrini and parasite infections from Thai labourers in Taiwan. J Helmintho 1993; 67: 102-6.

[13] Cheng HS, Haung ZF, Lan WH, Kuo TC, Shin JW. Epidemiology of Blastocystis hominis and other intestinal parasites in a Vietnamese female immigrant population in southern Taiwan. Kaohsiung J Med Sci 2006; 22: 166-70.

[14] Su FH, Chu FY, Li CY, et al. Blastocystis hominis infection in long-term care facilities in Taiwan: prevalence and associated clinical factors. Parasitol Res 2009; 105: 1007-13.

[15] Lee JD, Wang JJ, Leu SN, et al. Investigation on the parasitic infections in alien laborers in Kaohsiung from Aug 1994 to Jun 1995. Chinese J Parasitol 1996; 9: 35-42.

[16] Wang LC. Parasitic infections among Southeast Asian Laborers in Taiwan: a long term study. Epidemiol Infect 1998; 102: 81-6.

[17] Fan PC. Review on imported parasites from foreign laborers in Taiwan. Chinese J Parasitol 1999; 12: 35-49.

[18] Appendix: Principles in determining the health status failed [http://www.immigration.gov.tw/ct.asp?xItem $=1083417 \&$ ctNode $=$ $29649 \& \mathrm{mp}=1]$

[19] Sapero J, Lawless D. The "MIF" stain- preservation technic for the identification of intestinal protozoa. Am J Trop Med Hyg 1953; 2: 613-9.

[20] Chen ER. Current status of food-borne parasitic zoonoses in Taiwan. Southeast Asian J Trop Med Public Health 1991; 22 Suppl: 62-4.

[21] Yeh TC, Lin PR, Chen ER, Shaio MF. Current status of human parasitic infections in Taiwan. J Microbiol Immunol Infect 2001; 34: $155-60$

[22] Fan PC, Chung WC. Parasitic Infction Among Foreign Workers in Northern Taiwan. Chinese J Parasitol 1996; 9: 9-17.

[23] Lee JD, Wang JJ, Leu SN, et al. Investigation on the Parasitic infection in Alien Labouers in Kaohsiung from august 1994 to June 1995. Chinese J Parasitol 1996; 9: 35-42.

(C) Hsieh et al.; Licensee Bentham Open.

This is an open access article licensed under the terms of the Creative Commons Attribution Non-Commercial License (http://creativecommons.org/licenses/ by-nc/3.0/) which permits unrestricted, non-commercial use, distribution and reproduction in any medium, provided the work is properly cited. 